\title{
LSTM Network and OCR Performance for Classification of Decimal Dewey Classification Code
}

\author{
Performansi LSTM Network dan OCR untuk \\ Klasifikasi Kode Decimal Dewey Classification
}

\section{Yesy Diah Rosita dan Yanuarini Nur Sukmaningtyas}

Paper Type:

Universitas Islam Majapahit

Research Paper

\section{Abstract}

Background of the study: Giving book code by a librarian in accordance with the Decimal Dewey Classification system aims to facilitate the search for books on the shelf precisely and quickly.

Purpose: The first step in giving code to determine the class of books is the principal division which has 10 classes.

Method: This study proposed Optical Character Recognition to read the title text on the book cover, preprocessing the text, and classifying it by Long Short-Term Memory Neural Network.

Findings: In general, a librarian labeled a book by reading the book title on the book cover and doing book class matching with the book guide of DDC. Automatically, the task requires time increasingly. We tried to classify the text without OCR and utilize OCR which functions to convert the text in images into text that is editable. BY the experimental result, the level of classification accuracy without utilizing OCR is higher than using OCR.

Conclusion: The magnitude of the accuracy is $88.57 \%$ and $74.28 \%$ respectively. However, the participation of OCR in this classification is quite efficient enough to assist a beginner librarian to overcome this problem because the accuracy difference is less than $15 \%$.

Keywords: librarian, library, text 


\begin{abstract}
Abstrak
Latar Belakang Masalah: Pemberian kode buku oleh pustakawan sesuai dengan sistem Decimal Dewey Classification (DDC) bertujuan untuk memudahkan pencarian buku di rak secara tepat dan cepat.

Tujuan: Langkah pertama dalam memberikan kode untuk menentukan kelas buku adalah divisi utama yang memiliki 10 kelas.

Metode Penelitian: Secara otomatis, tugas ini membutuhkan waktu yang semakin lama. Penelitian ini mengusulkan Optical Character Recognition (OCR) untuk membaca teks judul pada sampul buku, preprocessing teks, dan mengklasifikasikannya dengan Long Short-Term Memory (LSTM) Network.

Temuan: Secara umum, pustakawan memberi label buku dengan membaca judul buku di halaman depan (sampul buku) dan melakukan kelas buku yang sesuai dengan pedoman DDC. Kami mencoba untuk mengklasifikasikan teks tanpa OCR dan menggunakan OCR yang berfungsi untuk mengubah teks dalam gambar menjadi teks yang dapat diedit. Berdasarkan hasil percobaan, tingkat akurasi klasifikasi tanpa menggunakan OCR lebih tinggi daripada menggunakan OCR.

Kesimpulan Besarnya akurasi adalah masing-masing 88,57\% dan 74,28\%. Namun, performansi OCR dalam klasifikasi ini cukup efisien untuk membantu pustakawan pemula dalam mengatasi masalah ini karena perbedaan akurasi kurang dari $15 \%$.
\end{abstract}

Kata Kunci: perpustakaan, pustakawan, teks 


\section{Pendahuluan}

Pada kegiatan pemberian notasi buku, pustakawan mencocokkan keyword atau subjek ke bagan klasifikasi buku. Pedoman yang sering digunakan untuk mengklasifikasikan buku berdasarkan subjeknya menggunakan sistem DDC (Decimal Dewey Classification). Decimal Dewey Classification merupakan sistem klasifikasi perpustakaan yang pertama kali diterbitkan di Amerika Serikat oleh Melvil Dewey (Dewey, 1876). Selain itu, DDC sudah digunakan oleh 200.000 perpustakaan dengan setidaknya 135 negara (Joudrey, Taylor, \& Miller, 2015; Service, 2009). Namun, jumlah klasifikasi buku yang terdapat pada DDC relatif banyak, sehingga dibutuhkan waktu dalam pencarian notasi klasifikasi buku. Dalam hal ini, klasifikasi buku disebut sebagai kelas. DDC terbagi menjadi 3 bagian klasifikasi yakni klasifikasi utama, klasifikasi divisi, dan klasifikasi seksi. Jumlah notasi yang terdapat pada masing-masing klasifikasi secara berturut-turut adalah 10 kelas, 100 kelas, dan 1000 kelas.

Pada umumnya, seorang pustakawan mampu mengetahui jenis klasifikasi buku dengan membaca judul buku yang tertera pada halaman depan buku atau lebih dikenal dengan book cover karena sudah dapat mewakili isi buku. Untuk mengetahui notasi / kode klasifikasi utama buku, dibutuhkan waktu untuk mencocokkan subjek buku dengan pedoman DDC. Padahal jumlah buku yang diterima oleh perpustakaan sangat banyak, sehingga diperlukan kecepatan dan ketepatan dalam pemberian notasi pada buku. Sebagai langkah awal yang perlu dilakukan adalah pemberian notasi klasifikasi utama. Hal ini diperlukan untuk lebih mempermudah dalam pemberian notasi klasifikasi berikutnya.

Klasifikasi buku dapat dilihat berdasarkan pola teks pada judul buku yakni subjek buku, seperti halnya klasifikasi dokumen (Alfian Sukma, Badrus Zaman, 2015; Bijalwan, Kumar, Kumari, \& Pascual, 2014). Terdapat beberapa metode yang dapat digunakan untuk mengetahui pola teks serta mengklasifikasikannya. Namun masing-masing metode yang digunakan pada penelitian-penelitian sebelumnya memiliki tingkat ketepatan yang berbeda. Adapun state of art penelitian ini tersaji pada tabel 1 .

Tabel 1. State of Art

\begin{tabular}{|c|c|c|c|c|c|}
\hline No & Model & Topik & $\begin{array}{l}\text { Metode yang } \\
\text { digunakan }\end{array}$ & Pengukuran & Hasil \\
\hline 1. & $\begin{array}{l}\text { Junkai Yi, et. } \\
\text { al, } 2017\end{array}$ & $\begin{array}{l}\text { Klasifikasi } \\
\text { informasi penting } \\
\text { pada internet }\end{array}$ & $\begin{array}{l}\text { Deep-Learning } \\
\text { Vocabulary Network } \\
\text { (DLVN), Vector Space } \\
\text { Model (VSM), Term } \\
\text { Frequency-Inverse }\end{array}$ & $\begin{array}{l}\text { Jarak } \\
\text { Euclidience }\end{array}$ & $\begin{array}{l}14.48 \\
13.75 \\
13.87\end{array}$ \\
\hline 2. & $\begin{array}{l}\text { Sandeep Kaur, } \\
\text { et.al., } 2016\end{array}$ & $\begin{array}{l}\text { Klasifikasi berita } \\
\text { online }\end{array}$ & $\begin{array}{l}\text { Neural Network } \\
\text { Classifier }\end{array}$ & Accuracy & $99.39 \%$ \\
\hline 3. & $\begin{array}{l}\text { Doaa Mohey } \\
\text { El-Din, } 2016\end{array}$ & $\begin{array}{l}\text { Klasifikasi ulasan } \\
\text { artikel ilmiah } \\
\text { online }\end{array}$ & $\begin{array}{l}\text { Bag-of-Words Model, } \\
\text { Term Frequency- } \\
\text { Inverse }\end{array}$ & Accuracy & $81.7 \%$ \\
\hline 4. & $\begin{array}{l}\text { Chunting } \\
\text { Zhou, et. al., } \\
2015\end{array}$ & Klasifikasi Teks & $\begin{array}{l}\text { C-Long Short-Term } \\
\text { Memory Network }\end{array}$ & Accuracy & $94,60 \%$ \\
\hline 5. & $\begin{array}{l}\text { Vishwanath } \\
\text { Bijalwan, et. } \\
\text { al., } 2014\end{array}$ & $\begin{array}{l}\text { Klasifikasi artikel } \\
\text { berita }\end{array}$ & $\begin{array}{l}\text { Naive Bayes, Term } \\
\text { Graph, dan K Nearest } \\
\text { Neighbour (KNN) }\end{array}$ & Accuracy & $\begin{array}{l}62.66 \%, \\
98.73 \%,\end{array}$ \\
\hline 6. & $\begin{array}{l}\text { Faisal } \\
\text { Mohammad, } \\
\text { et. al., } 2014\end{array}$ & $\begin{array}{l}\text { Menerjemahkan } \\
\text { tulisan tangan } \\
\text { berbentuk gambar } \\
\text { ke dalam bentuk } \\
\text { teks yang } \\
\text { bersifat editable }\end{array}$ & $\begin{array}{l}\text { Model Optical } \\
\text { Character Recognition } \\
(\text { OCR })\end{array}$ & $\begin{array}{l}\text { Tingkat } \\
\text { Pengenalan }\end{array}$ & $75 \%$ \\
\hline
\end{tabular}


Sistem yang akan dibangun untuk menyelesaikan permasalahan tersebut terdiri dari 3 tahap, yaitu: tahap pembacaan judul teks buku (book cover), tahap ektraksi teks, dan tahap klasifikasi teks. Konsep yang akan digunakan untuk membaca teks pada book cover adalah Optical Character Recognition (OCR). Konsep ini merupakan cabang disiplin ilmu dari computer science yang mempunyai fungsi pembacaan teks yang berasal dari hasil scan gambar yakni menerjemahkan bentuk tulisan pada gambar ke dalam bentuk teks yang dapat di edit (Isheawy \& Hasan, 2015; Mohammad, Anarase, Shingote, \& Ghanwat, 2014; Vijayarani \& Sakila, 2017). Hasil dari pembacaan teks pada gambar akan diekstrak terlebih dahulu untuk mendapatkan karateristik teks seperti kata dasar dan penghapusan kata yang tidak diperlukan (contoh: yang, ke, pada, dan, terdapat, dan sebagainya). Kemudian hasil ektraksi teks disimpan sistem dalam sebuah dataset (tempat penyimpanan data) sebagai data training. Data ini digunakan sistem dalam pelatihan (training) untuk pengklasifikasian kelas buku hingga membentuk sebuah classifier (pengklasifikasi). Metode yang digunakan untuk membentuk classifier yakni Neural Network (NN) karena merupakan teknik klasifikasi teks dengan akurasi lebih dari $90 \%$ (Kaur \& Khiva, 2016). Setelah didapatkan classifier dengan performansi yang baik maka classifier tersebut dapat digunakan untuk mengklasifikasikan judul pada book cover. Adapun tujuan utama dari penelitian ini yaitu pustakawan tingkat pemula mampu mengetahui klasifikasi utama buku berdasarkan judul buku dengan lebih mudah dan tepat dengan memanfaatkan kamera untuk mengambil gambar book cover. Hal ini sangat diperlukan sebagai langkah awal untuk mengetahui bagian klasifikasi berikutnya karena tergantung dari klasifikasi utama.

Berdasarkan state of art pada tabel 1 maka model dan metode yang digunakan pada penelitian ini diantaranya: Optical Character Recognition (OCR), Bag-of-Word, Term Frequency - Inverse Document Frequency (TF-IDF) serta Neural Network (NN).

\section{Optical Character Recognition (OCR)}

Optical Character Recognition (OCR) merupakan proses penerjemah teks yang mengubah gambar ke dalam bentuk teks yang berbentuk editable (dapat di-edit) (Isheawy \& Hasan, 2015; Mohammad et al., 2014; Vijayarani \& Sakila, 2017). Hasil penerjemahan ini mengakibatkan ukuran file teks yang berbentuk editable jauh lebih kecil daripada teks yang berbentuk gambar. Dengan kata lain, hasil penerjemahan teks yang berbentuk gambar menjadi karakter ASCII. Adapun mekanisme penggunaan model OCR sebagai berikut:

a) Binarization, proses konversi gambar RGB (red green blue color) ke biner (black and white color).

b) Noise Filtering, proses untuk menghilangkan bagian piixel yang dianggap tidak penting.

c) Segmentation, pemisahan area pada setiap karakter yang terdeteksi.

d) Normalization, proses penskalaan (scaling) dan penebalan (thinning) karakter agar didapatkan ukuran yang sama.

e) Feature Extraction, proses pengambilan fitur-fitur setiap karakter.

f) Pencocokan karakter, penghitungan jarak kedua vektor karakter (acuan dan input) dengan menggunakan perhitungan jarak Euclidience Distance

\section{Bag-of-Words (BoW)}

Bag-of-words merupakan teknik yang banyak digunakan untuk sentiment analysis namun mempunyai 2 kelemahan yakni penggunaan evaluasi secara manual untuk leksikon dalam penentuan evaluasi kata-kata dan menganalisis tingkat sentimental kata dengan akurasi rendah karena mengabaikan efek tata bahasa dari kata-kata dan mengabaikan semantik kata-kata (Mohey, 2016). Selain itu, BoW dikenal juga sebagai term-frequency counter (Mathworks, 2018b). Model bag-of-words mencatat berapa kali kata-kata itu muncul di setiap kumpulan dokumen. Adapun tahapannya anatara lain:

a) Tokenization, proses pembagian teks ke dalam bagian sendiri-sendiri. Misal terdapat sebuah teks "majapahit terletak di mojokerto" maka menjadi "majapahit," "terletak," "di," dan 
"mojokerto." Proses ini juga disisipi fungsi lowercase yang bertujuan menjadikan semua kata berbentuk huruf kecil.

b) Remove Stop Word, proses penghilangan kata-kata yang tidak penting yang telah ditentukan. Misal, daftar kata yang tidak penting seperti "yang," "di," "ke," "pada," "saat," dsb. Kemudian dicocokkan dengan hasil tokenization keberadaan stop word. Jika ada, maka kata tersebut dihilangkan.

c) Vectorization, proses konversi teks ke bentuk vektor dengan mencocokkan unique words (kata unik). Misal terdapat 10 unique words antara lain "universitas," "islam," "majapahit," "kerajaan," "mojokerto," "gajah," "mada," "kampus," "kuliah," "museum." Kemudian jika terdapat sebuah teks berisi "universitas islam majapahit mojokerto panorama hijau" menjadi [1

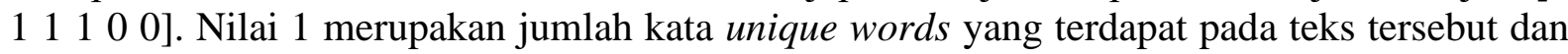
sebaliknya.

\section{Term Frequency - Inverse Document Frequency (TF-IDF)}

Metode ini digunakan untuk mengevaluasi pentingnya kata pada sebuah teks atau dokumen dengan pemberian bobot (Man Lan, Chew Lim Tan, Jian Su, \& Yue Lu, 2009).

a) Term Frequency (TF), merupakan jumlah kemunculan kata pada dokumen.

$$
T F=\left\{\begin{array}{c}
1+\log _{10} f(t, d) ; f(t, d)>0 \\
0 ; f(t, d)=0
\end{array}\right.
$$

Keterangan:

$f(t, d)$ : jumlah kata/term pada sebuah dokumen.

b) TF normalization, merupakan perbandingan frekuensi kata/term dengan nilai maksimum dari keseluruhan frekuensi kata pada sebuah dokumen.

$$
T F \_ \text {Normalization }=0.5+0.5 x\left[\frac{f(t, d)}{\max \left\{f\left(t^{\prime}, d\right): f\left(t^{\prime}, d\right), d \in d\right\}}\right]
$$

c) Inverse Document Frequency (IDF), merupakan proses yang mampu menunjukkan bahwa seberapa besar keterkaitan kata terhadap keseluruhan dokumen.

$$
I D F_{j}=\log \left(D / d f_{j}\right)
$$

Keterangan:

$D \quad$ : jumlah keseluruhan dokumen

$d f_{j} \quad$ : jumlah dokumen yang mengandung kata/term yang dimaksud.

Kemudian dilanjutkn dengan pembobotan dengan menggunakan persamaan 4.

$$
w_{i j}=t f_{i j} \cdot \log \left(D / d f_{j}\right)+1
$$

Keterangan:

$t f_{i j} \quad$ : term frequency pada dokumen

$D \quad$ : jumlah dokumen keseluruhan

$d f_{j} \quad$ : jumlah dokumen yang mengandung term/kata

Hasil dari pembobotan ini akan digunakan untuk mengetahui kecenderungan kelas dokumen.

\section{Long Short-Term Memory (LSTM) Network}

Sebuah merupakan kata-kata terurut yang saling memiliki ketergantungan satu dengan lainnya. LSTM Network adalah jenis Recurrent Neural Network (RNN) yang mampu mempelajari ketergantungan tersebut (Service, 2009; Zazo, Lozano-Diez, Gonzalez-Dominguez, Toledano, \& Gonzalez-Rodriguez, 2016; Zhou, Sun, Liu, \& Lau, 2015). Mekanisme LSTM network sama seperti Neural Network (NN) lainnya. Namun, untuk pengklasifikasian data teks, diperlukan pengonversian data teks ke dalam bentuk numerik dengan fungsi word embeddings. Fungsi ini dapat mengetahui secara detail semantik dari kata-kata, sehingga apabila terdapat kata-kata yag mirip, maka akan 
menghasilkan vektor yang sama. Misal, jika digambarkan hubungan antara kata-kata dengan aritmatika vektor seperti teks yang berisi "king is to queen as man is to woman" menjadi persamaan "king" "man" + "woman" = "queen".

Pertama, unit LSTM menentukan status awal jaringan dan langkah pertama dari $X_{1}$ squence, lalu menghitung output pertama $h_{1}$ dan memperbarui cell state $c_{1}$. Pada saat langkah $t$, unit menempati current state jaringan $\left(c_{t-1}, h_{t-1}\right)$ dan langkah berikutnya $X_{1}$ squence, dan menghitung output $h_{1}$ serta memperbarui cell state $c_{t}$.

Layer state terdiri dari output state (hidden state) dan cell state. Output state pada step $t$ terdiri output dari layer LSTM. Cell state terdiri informasi pembelajaran dari step sebelumnya. Pada setiap step, layer menambahkan atau mengurangi informasi dari cell state dimana layer mengontrol perubahan ini menggunakan gates.

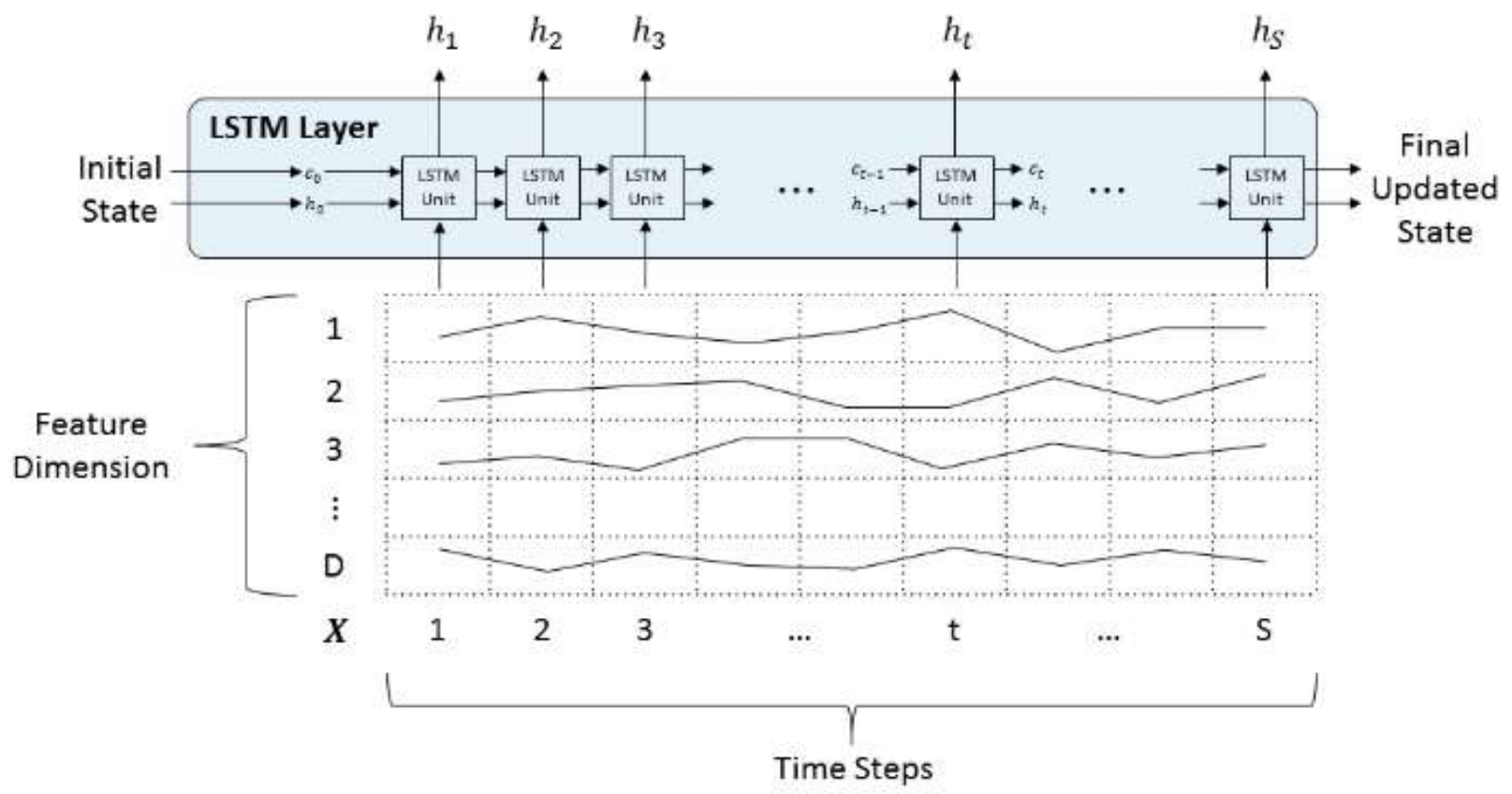

Gambar 1. Arsitektur LSTM Networks (Sumber: http://mathworks.com)

Tabel 2. Komponen Layer LSTM Network

\begin{tabular}{ccl}
\hline No. & Komponent & \multicolumn{1}{c}{ Fungsi } \\
\hline 1. & Input gate $(i)$ & Mengontrol level perubahan cell state \\
2. & Forget gate $(f)$ & Mengontrol level ulang cell state (lupa) \\
3. & Layer input $(g)$ & Menambah informasi pada cell state \\
4. & Output gate $(o)$ & Mengontrol level cell state ditambahkan ke output state \\
\hline
\end{tabular}

\section{Metode Penelitian}

Sebelum dilakukan penelitian, terdapat beberapa hal yang harus dipersiapkan terlebih dahulu, seperti tool yang digunakan dalam penelitian ini. Tool yang digunakan untuk mendukung penelitian ini adalah software Matlab R2018a. Software ini sangat populer digunakan para peneliti tingkat internasional karena fitur-fitur yang dimilikinya hampir lengkap untuk dipergunakan para peneliti. Sedangkan data yang digunakan adalah informasi mengenai buku perpustakaan. 


\section{Dataset}

Data diambil secara acak mulai dari perpustakaan kampus terdekat (Mojokerto-Jombang, Jawa Timur, Indonesia) dengan mengamati judul buku dan kode DDC pada label buku yang tertera dan sudah ditetapkan oleh pustakawan setempat. Selain itu, data diperoleh dari dataset yang terdapat di internet seperti Github dataset (Brian Kenji Iwana, Rizvi, Ahmed, Dengel, \& Uchida, 2017), OCLC (Online Computer Library Center), dan perpustakaan online Oxford University. Alasan utama pengambilan data pada perpustakaan adalah klasifikasi buku telah diverifikasi dan ditetapkan oleh pustakawan sesuai pedoman DDC. Data yang diperoleh berupa judul buku, kode DDC, dan gambar cover buku untuk digunakan saat uji coba. Data dalam hal ini dibagi menjadi 2 bagian yakni data training dan data testing. Jumlah data sebanyak 15.000 data yang terdiri dari 14.930 data training dan sisanya dipergunakan untuk data testing. Parameter yang digunakan sebagai kelas atau output dari penelitian ini adalah kode DDC klasifikasi utama. Banyaknya jumlah data yang digunakan ini menyebabkan waktu yang dibutuhkan untuk pengumpulan data berlangsung selama kurang lebih 4 bulan. Peneliti melakukan pemindahan data per buku. Berbeda dengan data yang diperoleh dari Github dataset yang diperoleh dari Amazon.com (B. K. Iwana, Rizvi, Ahmed, Dengel, \& Uchida, 2016). Peneliti hanya men-download data dari sumber tersebut yang telah disediakan meskipun kelas dari data tersebut bukan merupakan kode DDC namun dapat dikonversikan dengan kategori kelas yang ada. Proses konversi ini dapat dilakukan karena pada kategori kelas pada dataset tersebut merupakan subjek buku yang termasuk klasifikasi utama. Tingkat performansi sebuah classifier (pengklasifikasi) teks yang baik tidak hanya dipengaruhi banyaknya data yang digunakan sebagai data training, namun perlu diperhatikan kualitas teks yang digunakan apakah mengandung unsur ambiguitas atau bukan.

Tabel 3. Kode Divisi Utama Decimal Dewey Classification (DDC) System

\begin{tabular}{ccl}
\hline No. & Kode & \\
\hline 1. & 000 & Computer science, information and general works \\
2. & 100 & Philosophy and psychology \\
3. & 200 & Religion \\
4. & 300 & Social sciences \\
5. & 400 & Language \\
6. & 500 & Pure Science \\
7. & 600 & Technology \\
8. & 700 & Arts and recreation \\
9. & 800 & Literature \\
10. & 900 & History and geography \\
\hline
\end{tabular}

Terdapat perbedaan antara data yang dipergunakan untuk proses training dan testing yakni gambar cover buku. Pada data training tidak mempergunakan gambar cover buku dan sebaliknya. Hal ini dimaksudkan untuk proses ujicoba ketika pemanfaatan OCR dalam pembacaan teks pada gambar sebelum dilakukan klasifikasi teks.

\section{Desain Sistem}

Pada penelitian ini, perlu dilakukan pembentukan sebuah classifier teks kelas buku 
berdasarkan judul buku tersebut. Langkah yang pertama adalah teks pada data training dilakukan pre-processing terlebih dahulu yakni proses menormalisasikan teks sehingga didapatkan kata-kata yang murni tanpa ada unsur yang tidak diperlukan seperti imbuhan, tanda baca, nomer, dan kata-kata yang termasuk dalam stop word list. Tahapan pre-processing terdiri dari lower case convertion, erase punctuation, tokenization, removal stop word list, stemming, dan removal short words.

a) Lower case convertion adalah proses mengubah huruf besar pada teks menjadi huruf kecil. Hal ini bertujuan untuk menyeragamkan huruf pada teks. Contoh, terdapat sebuah teks berisi "Decision Support System for Business.", maka hasil yang didapatkan adalah "decision support system for business".

b) Tahap kedua adalah erase punctuation yakni menghilangkan tanda baca atau segala bentuk simbol yang notabene tidak memiliki makna yang penting pada teks, seperti tanda baca titik (.), tanda tanya (?), tanda seru (!), dan sebagainya. Contoh, hasil lower case convertion sebelumnya dapat dihasilkan teks "decision support for system business." Simbol titik (.) dianggap simbol yang tidak memiliki makna penting atau suatu pertimbangan untuk menentukan kelas teks.

c) Tahap selanjutnya adalah tokenization. Proses ini memecah konten tekstual menjadi kata-kata, istilah simbol, atau beberapa elemen bermakna lainnya yang selanjutnya disebut sebagai token (Vijayarani \& Janani, 2016). Namun, token dipisahkan oleh karakter spasi. Contoh terdapat sebuah teks berisi "Decision Support System for Business", ketika dilakukan tokenization maka dihasilkan 5 token yakni "decision", "support", "system", "for", dan "business".

d) Tahap keempat adalah removal words. Istilah words dalam hal ini merupakan kata-kata yang tidak memiliki makna penting atau suatu pertimbangan untuk menentukan kelas teks seperti halnya punctuation (tanda baca) sebelumnya. Contoh kata yang dimaksud adalah "for", "of", " $a$ ", "the," dan semacamnya. Berdasarkan hasil tokenization, apabila dilakukan removal words maka menghasilkan 4 token yakni "decision", "support", "system", dan "business".

e) Tahap kelima adalah stemming yang berfungsi menghilangkan imbuhan baik awalan maupun akhiran. Tujuan dari tahap ini adalah menghasilkan kata dasar atau mendekati kata dasar. Contoh, terdapat kata "business", apabila dilakakukan stemming maka menghasilkan "busi" karena kata "ness" merupakan imbuhan sehingga jumlah huruf pada kata tersebut menjadi berkurang.

f) Tahap terakhir adalah removal short words. Proses ini bertujuan menghilangkan semua kata yang terdiri dari jumlah kata yang relatif sedikit karena dianggap sebagai kata hubung seperti "of", "the", "for", dan semacamnya.

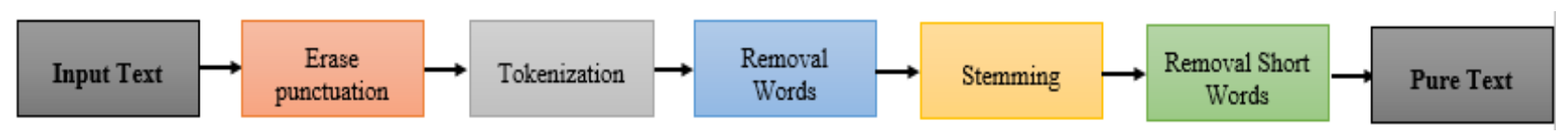

Gambar 2. Tahapan Preprocessing Teks

Hasil preprocessing teks pada data training dilakukan proses training untuk menghasilkan sebuah classifier. Metode yang digunakan untuk membentuk classifier ini adalah Long Short-Term Memory (LSTM) Neural Network. LSTM menunjukkan kinerja yang sangat tinggi dalam berbagai aplikasi meskipun memiliki kompleksitas dan komputasi yang relatif tinggi (Salehinejad, Sankar, Barfett, Colak, \& Valaee, 2017). Dalam penggunaan jaringan LSTM untuk data teks, terlebih dahulu mengubah data teks menjadi urutan numerik dengan menggunakan word embeddings yakni memetakan kata dalam kosakata ke vektor numerik (Mathworks, 2018a). Embeddings ini dapat menangkap detail semantik dari kata-kata, sehingga kata-kata yang mirip memiliki vektor yang sama. Mereka juga memodelkan hubungan antara kata-kata melalui aritmatika vektor. Sebagai contoh, hubungan "raja adalah ratu seperti laki-laki dengan perempuan" dijelaskan oleh persamaan raja - lakilaki + perempuan $=$ ratu. 


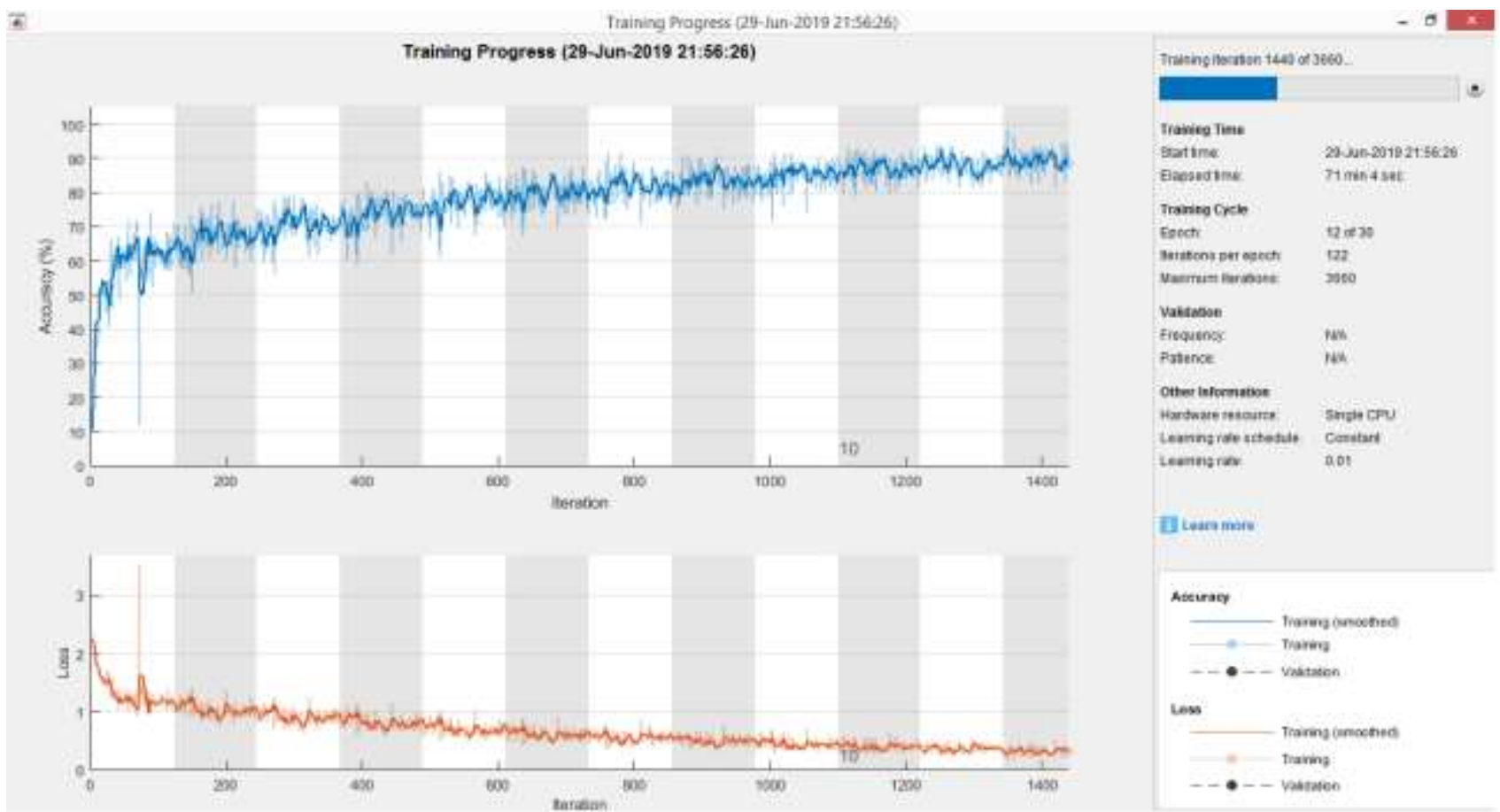

Gambar 3. Grafik Pembentukan Classifier dengan LSTM Network

Terdapat 3 tahapan dalam proses training menggunakan LSTM Network, antara lain:

a) Impor data dan dilanjutkan preprocessing data. Data terdiri dari 2 kolom yang memiliki header Content dan Label. Header content berisi judul buku, sedangkan label berisi kelas judul buku, yakni kode DDC divisi utama.

b) Ubah kata-kata menjadi vektor numerik dengan melatih (train) word embeddings.

c) Pembuatan, sekaligus melatih jaringan LSTM menggunakan urutan vektor kata. Pada dasarnya, LSTM merupakan salah satu metode pengembangan dari neural network yang melibatkan juga layer input. Ukuran input sama dengan dimensi dari embedding kata sedangkan ukuran output ditentukan menjadi 180, serta jumlah kelasnya sesuai dengan jumlah kode DDC divisi utama. Dalam penggunaan layer LSTM untuk masalah klasifikasi sequence-to-label, diatur mode output menjadi "last" dan inisialiasi learn rate (tingkat pembelajaran classifier) sebesar 0.01 . Selanjutnya, menambahkan layer yang sepenuhnya terhubung dengan ukuran yang sama dengan jumlah kelas, layer softmax, dan layer klasifikasi.

Pada saat proses training ditunjukkan tingkat grafik accuracy dan loss. Grafik tersebut akan menggambarkan seberapa besar performansi dari classifier yang dibentuk, semakin accuracy mendekati nilai 100 dan loss semakin mendekati nilai 0 maka performansi classifier yang dibentuk semakin baik. Selain itu, grafik tersebut akan menunjukkan jumlah iterasi, waktu yang dibutuhkan training serta semua yang berhubungan dengan kedua hal tersebut.

Ketika sebuah classifier telah didapatkan, maka classifier tersebut dapat dipergunakan untuk mengklasifikasikan data testing. Pada penelitian ini, proses pengklasifikasian teks tidak dilakukan secara langsung. Namun, pemanfaatan Optical Character Recognition (OCR) untuk membaca teks judul yang terdapat pada cover buku. Proses ini melalui scanning (pemindahan) cover buku yang berupa gambar dikonversikan dalam bentuk teks, sehingga teks tersebut dapat dilanjutkan ke proses. 


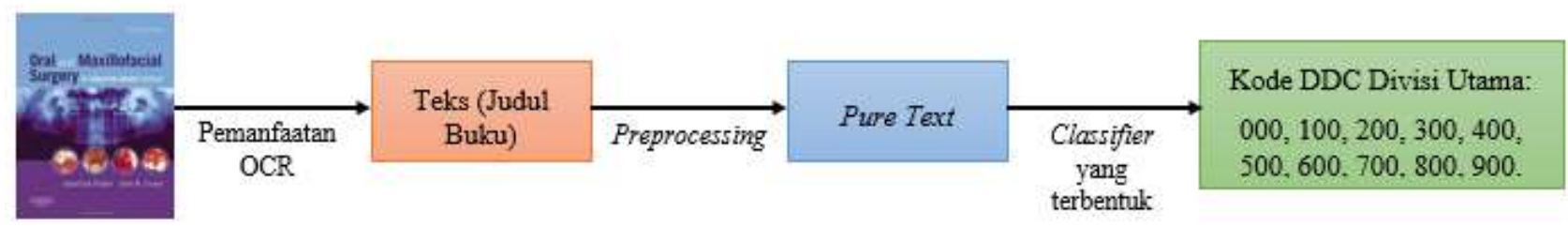

Cover Buku

Gambar 4. Tahapan Pengklasifikasian Jenis Buku berdasarkan Judul Buku

\section{Hasil dan Diskusi}

Uji coba dilakukan terhadap data testing dengan jumlah 70 data. Masing-masing kelas terdiri dari 10 macam judul buku. Uji coba yang dilakukan ini terdiri dari dari 2 perlakuan, yaitu klasifikasi teks judul secara langsung dan klasifikasi teks judul buku yang diperoleh dari penggunaan OCR. Hal ini diperlukan untuk mengetahui performansi LSTM dan OCR itu sendiri apakah lebih baik menggunakan OCR atau sebaliknya. Selain itu, dipertimbangkan pula dari segi efisiensinya dalam penentuan kelas buku dengan menggunakan cover buku yang berisi judul buku.

Berdasarkan hasil ujicoba yang dilakukan didapatkan tingkat akurasi yang berbeda. Klasifikasi teks secara langsung tanpa memanfaatkan OCR mencapai 88.57\%. Namun, ketika penggunaan OCR dalam pembacaan judul teks pada cover buku, classifier yang dibentuk dapat mengklasifikasikannya sebesar 74.28\%. Hal ini, disebabkan karena pemanfaatan OCR terdapat 6 tahapan hingga didapatkan teks, sehingga sangat dimungkinkan terjadinya pengikisan jumlah kata dan kata-kata yang tak memiliki arti. Selain itu, masih terdapat beberapa hal yang perlu diperhatikan. Hasil scanning cover buku yang dihasilkan memiliki tingkat kecerahan yang rendah sehingga mempengaruhi kejelasan tulisan. Di lain hal, apabila cover buku di-scan secara keseluruhan maka penangkapan judul teks disertai dengan nama penerbit, penulis, dan kota/tempat sehingga menambah kata-kata yang tidak penting ketika dilakukan pengklasifikasian.

Dilihat dari sisi performansi LSTM Network, penggunaan data training, adanya teks-teks yang bersifat ambigu terhadap kode DDC divisi utama sebagai kelas buku, juga mempengaruhi tingkat akurasi dari classifier tersebut. Sebagai contoh, terdapat suatu teks mengandung unsur tulisan "computer" yang termasuk kategori Computer science, information and general works dengan kode DDC divisi utama 000 juga termasuk kategori Technology dengan kode DDC divisi utama 600. Hal ini mempengaruhi tingkat akurasi uji coba, karena tergantung kualitas dan jumlah data yang digunakan pada data training, selain arsitektur jaringan LSTM Network yang dibentuk. Meskipun begitu, dari segi efisiensi dalam pengklasifikasian buku yang dapat diaplikasikan oleh seorang pustakawan pemula cukup membantu dalam pemberian notasi buku sebagai langkah awal untuk mengetahui klasifikasi berikutnya.

\section{Kesimpulan}

Banyaknya tahapan pada preprocessing memiliki kelebihan dan kelemahan. Kelebihannya adalah teks yang didapatkan terbebas dari kata-kata/simbol yang tidak memiliki makna penting, sehingga didapatkan teks dengan kata dasar yang mendekati sempurna. Sebaliknya, semakin banyak tahapan preprocessing yang diperlukan maka secara otomatis durasi proses komputasi juga semakin tinggi.

Pembentukan sebuah classifier teks dengan LSTM Network tergantung dari data training yang digunakan. Data tersebut memiliki jumlah data yang cukup dan terhindar dari data yang bersifat ambigu. Selain hal tersebut, pembentukan jaringan LSTM mempunyai peran penting juga untuk menghasilkan performansi sebuah classifier. Terdapat inisialiasi variabel yang diperlukan seperti ukuran input dan output, learn rate, output mode, layer softmax, dan layer klasifikasi.

Penggunaan OCR ditujukan untuk membantu seorang pustakawan dalam penginputan judul 
teks secara efisien dengan cukup mengarahkan cover buku terhadap web camera atau scanner. Namun perlu dicatat, proses scanning tidak perlu dilakukan secara keseluruhan pada cover buku karena yang dibutuhkan hanya judul buku saja. Hal ini dimaksudkan untuk mendapatkan tingkat akurasi yang baik. Penggunaan OCR sebelum dilakukan pengklasifikasian dengan LSTM Network, memiliki tingkat akurasi lebih rendah dibandingkan tanpa menggunakan OCR, dengan selisih akurasi sebesar 14.29\%. Hal ini, disebabkan dengan beberapa kemungkinan seperti, tulisan pada book cover dianggap kurang jelas sehingga dianggap sebagai noise (kotoran) dan spesifikasi kamera yang digunakan untuk capturing/scanning sebuah cover buku yang dapat mempengaruhi kualitas gambar untuk memperoleh teks buku. Hasil eksperimen yang telah dilakukan menunjukkan bahwa penggunaan LSTM dapat bekerja dengan baik untuk klasifikasi teks buku, namun dapat juga dipengaruhi oleh hasil penggunaan dari OCR itu sendiri.

\section{Ucapan Terima Kasih}

Kami ucapkan terima kasih kepada Kementerian Riset, Teknologi, Pendidikan Tinggi (Kemenristekdikti) Republik Indonesia atas pendanaan sepenuhnya pada penelitian ini.

\section{Referensi}

Alfian Sukma, Badrus Zaman, E. P. (2015). Klasifikafi Dokumen Temu Kembali Informasi dengan K-Nearest Neghbour. Record and Library Journal of Airlangga University, 1, 129-138.

Bijalwan, V., Kumar, V., Kumari, P., \& Pascual, J. (2014). KNN based machine learning approach for text and document mining. International Journal of Database Theory and Application, 7(1), 61-70. https://doi.org/10.14257/ijdta.2014.7.1.06

Dewey, M. (1876). Classification and Subject Index for Cataloguing and Arranging the Books and Pamphlets of a Library (Project Gutenberg eBook).

Isheawy, N. A. M., \& Hasan, H. (2015). Optical Character Recognition (OCR) System. IOSR Journal of Computer Engineering Ver. II, 17(2), 2278-2661. https://doi.org/10.9790/0661-17222226

Iwana, B. K., Rizvi, S. T. R., Ahmed, S., Dengel, A., \& Uchida, S. (2016). Judging a Book by its Cover. arXiv prep.

Iwana, Brian Kenji, Rizvi, S. T. R., Ahmed, S., Dengel, A., \& Uchida, S. (2017). Judging a Book By its Cover. Computer Vision and Pattern Recognition.

Joudrey, D. N., Taylor, A. G., \& Miller, D. P. (2015). Introduction to Cataloging and Classification, 11th Edition.

Kaur, S., \& Khiva, N. K. (2016). Internal News Classification Using Deep Learning. 1(1), 31-35.

Man Lan, Chew Lim Tan, Jian Su, \& Yue Lu. (2009). Supervised and Traditional Term Weighting Methods for Automatic Text Categorization. IEEE Transactions on Pattern Analysis and Machine Intelligence, 31(4), 721-735. https://doi.org/10.1109/TPAMI.2008.110

Mathworks. (2018a). LSTM Layer. In Matlab Documentation.

Mathworks. (2018b). Texture Analysis.

Mohammad, F., Anarase, J., Shingote, M., \& Ghanwat, P. (2014). Optical Character Recognition Implementation Using Pattern Matching. Iternational Journal of Computer Science and Information Technologies, 5(2), 2088-2090.

Mohey, D. (2016). Enhancement Bag-of-Words Model for Solving the Challenges of Sentiment Analysis. International Journal of Advanced Computer Science and Applications, 7(1), 244-252. https://doi.org/10.14569/ijacsa.2016.070134

Salehinejad, H., Sankar, S., Barfett, J., Colak, E., \& Valaee, S. (2017). Recent Advances in Recurrent Neural Networks. 1-21. Retrieved from http://arxiv.org/abs/1801.01078

Service, D. (2009) Offers Library Users Familiarity and Consistency of a Timehonored Classification System Used in 200,000 Libraries Worldwide.

Vijayarani, S., \& Janani, R. (2016). Text Mining: open Source Tokenization Tools - An Analysis. Advanced Computational Intelligence: An International Journal (ACII), 3(1), 37-47. https://doi.org/10.5121/acii.2016.3104

Vijayarani, S., \& Sakila, A. (2017). Online Optical Character Recognition (OCR) Tools - Performance Analysis. International Journal of Advanced Research in Computer and Communication Engineering, 6(1), 55-58. https://doi.org/10.17148/IJARCCE

Zazo, R., Lozano-Diez, A., Gonzalez-Dominguez, J., Toledano, D. T., \& Gonzalez-Rodriguez, J. 
(2016). Language identification in short utterances using long short-term memory (LSTM) recurrent neural networks. PLoS ONE, 11(1). https://doi.org/10.1371/journal.pone.0146917

Zhou, C., Sun, C., Liu, Z., \& Lau, F. C. M. (2015). A C-LSTM Network for Text Classification. Retrieved from http://arxiv.org/abs/1511.08630 